\title{
THE
}

\section{Implicit Government Guarantee and the CDS Spreads}

Natalia Beliaeva

Shahriar Khaksari

Georges Tsafack

University of Rhode Island, gtsafack@uri.edu

Follow this and additional works at: https://digitalcommons.uri.edu/cba_facpubs

The University of Rhode Island Faculty have made this article openly available.

Please let us know how Open Access to this research benefits you.

This is a pre-publication author manuscript of the final, published article.

Terms of Use

This article is made available under the terms and conditions applicable towards Open Access Policy Articles, as set forth in our Terms of Use.

Citation/Publisher Attribution

Natalia Beliaeva, Shahriar Khaksari, and Georges Tsafack . (2015). "Implicit Government Guarantee and the CDS Spreads." Journal of Fixed Income, 25(2), 25-37. Available at: http://www.iijournals.com/doi/abs/ $10.3905 /$ jfi.2015.25.2.025

This Article is brought to you for free and open access by the College of Business at DigitalCommons@URI. It has been accepted for inclusion in College of Business Faculty Publications by an authorized administrator of DigitalCommons@URI.For more information, please contact digitalcommons-group@uri.edu. 


\title{
Implicit Government Guarantee and the CDS Spreads
}

\author{
Natalia Beliaeva \\ Suffolk University, Boston
}

\author{
Shahriar Khaksari \\ Suffolk University, Boston
}

\author{
Georges Tsafack \\ University of Rhode Island
}

\begin{abstract}
It is commonly agreed that the government is more likely to step in and rescue some troubled companies labeled as "Too-Big-to-Fail" or "Too-Interconnected-to-Fail". Since there is no formal contract between these companies and the government, this potential intervention is referred to as an implicit government guarantee. We propose a new approach of assessing and estimating the implicit government guarantee and analyze whether it is reflected in the CDS spreads. We define the implicit government guarantee for a given company as the probability that the government will bail it out in case of a default. Although the company's size affects the likelihood of the government intervention, we find that the financial industry membership is a more important factor. Furthermore, we find that the implicit government guarantee is priced into the CDS spreads. The government guarantee for the large companies reduces the CDS spread by about 16.11 bps and for the small companies only by about 3.73 bps. Similarly, for the financial industry we find that the government guarantee reduces the CDS spread by about 76.29 bps and for the non-financial industry only by about 7.50 bps.
\end{abstract}

JEL Classification: G28, G10, C13.

Keywords: Bailout, Implicit Guarantee, Too-Big-to-Fail, CDS Spread 


\section{Introduction}

Failure of some financial and non-financial firms may come at a very high cost to the society and have spillover effects across all sectors of the economy. To avoid crisis propagation, the government is likely to step in and rescue certain firms deemed "Too Big", "Too Important", or "Too Interconnected" to fail. Since companies do not pay for the possibility of being bailed out by the government who does not clearly indicate whether or not it will intervene, it can be considered an implicit government guarantee. The implicit government guarantee may vary from one firm to another depending on the characteristics of the firm, like the firm size, the sector, and the connection with the overall economy. Government propensity to intervene also changes across time. One of the side effects of the implicit government guarantee to the firm is that it may lead to the distorted perception about the company's risk of default by investors. The expectation that the government will intervene to protect the firm from failure biases investors' expectation about company's risk of default downward. The broadly used indicator of the level of company's perceived default risk is the CDS spread. The credit default swap (CDS) is the contract that protects the CDS buyer against the default of the referenced company. The CDS spread is the premium paid by the CDS buyer to the CDS seller for such protection. Since the CDS spreads could be affected by the implicit government guarantee, they might not fully reflect the underlying default risk of the firm. This has certain implications both from the regulators' and the investors' perspectives.

The contribution of this paper is twofold. First, we propose a new way of estimating the implicit government guarantee. The implicit government guarantee remains a public policy concern because it may involve transfer of resources from the government to the bailed out companies and, as the financial crises of 2007-2009 showed, the costs to the taxpayers and the society in general could be very high. Therefore, estimating the implicit government guarantee 
continues to be an important matter. Second, we explore the relationship between the CDS spreads and the implicit government guarantee. Our findings in this area have important implications, for example, for the estimation of the default probability and the amount of the regulatory capital.

The recent global financial crisis sparked a particular interest in estimating the value of the implicit government guarantee and a number of papers attempted to measure it using different approaches. One group of papers (see, for example, Noss and Sowerbutts [2012], Baker and McArthur [2009], and Li, Qu, and Zhang [2010]) relates implicit government guarantee to the cost of funding. They argue that in the presence of implicit government guarantee firms enjoy reduced cost of funding and a reduction in the cost of funding reflects the size of the implicit government guarantee. The actual strategy used for computing the government subsidy varies depending on the study. For example, Baker and McArthur [2009] use the difference in the funding costs between small and large US banks before and after TARP as an estimate for the subsidy. The main problem with this approach is that it makes an implicit assumption that only large financial institutions receive government support. Ueda and di Mauro [2012] and Haldane [2010] estimate the value of the government subsidy to the financial institutions based on the expectations of government support embedded in the company's credit ratings. Credit rating companies publish "individual" and "support" credit ratings. "Individual" rating assesses company's strength on a stand alone basis, whereas "support" rating incorporates the probability that the company will receive government support. The implicit government guarantee is estimated as a difference between bank's cost of funding implied by the "support" credit rating and the cost of funding implied by the "individual" credit rating. The general criticism of the rating based approach is that it is subject to credit rating agency's judgment regarding company's creditworthiness whereas credit rating agencies have been know to make mistakes in the past, for 
example, in rating structured securities. Another group of papers (see, for example, Gapen [2009], Lucas and McDonald [2009], and Oxera [2011]) attempts to measure the implicit government guarantee by using the contingent claims analysis. They represent the value of the implicit government guarantee as a put option on the firm's assets with the strike price equal to the firms' default barrier. The firm defaults when the value of the firm's assets falls below some threshold (e.g. promised payment on the debt) at some future time. If at maturity of the option the firm's assets value is above the default barrier, then the option is not exercised. However, if the firm's assets value falls below the threshold, then the option is exercised and its payoff is equal to the difference between the strike (the default barrier) and the value of the firm's assets. The implicit government guarantee is estimated as the expected value of the put option payoff. The contingent claims approach requires modeling the dynamics of a firm's future assets' values. For example, Gapen [2009] uses Black-Scholes-Merton option pricing model to compute the value of the implicit government guarantee to Fannie Mae and Freddie Mac. The shortcoming of the Black-Scholes-Merton model is that it assumes that the firm's (log) asset values are normally distributed which precludes the possibility of sudden changes in the firm's asset values. Both Lucas and McDonald [2009], and Oxera [2011] extend Black-Scholes-Merton model to incorporate the possibility of jumps in asset prices and investigate a wider range of parameter values. The main problem with the contingent claims approach is that it is very sensitive to the underlying assumptions and the model tends to get very complex as more realistic assumptions are made.

In this paper we propose a different methodology of estimating the implicit government guarantee. We define the implicit government guarantee as the probability that the government will bail out a firm facing default. To estimate the probability of the government intervention we use the Logit model which we apply to a set of 1209 bankrupt and bailed out companies between 
2000 and 2010. Then for a sample of companies with publicly available CDS spreads, we construct a government guarantee variable and investigate its relationship with the CDS spreads. Since the government guarantee reduces the risk of company's default, we expect the CDS spreads to be lower when the probability of the government intervention is high, that is we expect to find a negative relationship between the CDS spreads and the government guarantee variable. Our definition of the implicit government guarantee differs from the previous studies mainly in that it is simple, more intuitive and provides a clear interpretation. For instance, we can define the full government guarantee as a probability of one and no government guarantee as a probability of zero. By focusing on the value of the government guarantee other studies make it strongly dependent on the company's financial health. Companies in high default risk situation will see the value of their contingent claims increase even if the behavior of the government does not change. Our empirical analysis shows that, although the company's size affects the likelihood of the government intervention, the financial industry membership is a more important determinant. Furthermore, we find that the implicit government guarantee is indeed priced into the CDS spreads and the relationship is negative. The government guarantee for the large companies reduces the CDS spreads by about 16.11 bps and for the small companies only by about 3.73 bps. Similarly, for the finance industry we find that the government guarantee reduces the CDS spreads by about 76.29 bps and for the non-finance industry only by about 7.5 bps.

We also provide some practical implications of the relationship between the government guarantee and the CSD spreads both from the investors' and the regulators' perspectives. As the CDS spreads are often used in the finance industry to estimate the probability of default (PD) and the amount of the regulatory capital, we suggest that some adjustments should be used to account for the fact that the risk levels in the CDS spreads are based on the expectation of potential government intervention. In fact, the PD implied from the CDS spreads may be lower than the 
actual PD without government intervention. Therefore, we believe that a PD model should control for such possibility.

The remainder of the paper is organized as follows. Section 2 describes our methodology and the data set for estimating the government guarantee. Section 3 lays out the framework for analyzing the relationship between the implicit government guarantee and the CDS spreads and describes the CDS dataset along with the control variables we use in our analysis. Section 4 presents and summarizes our empirical findings. Section 5 provides further implications of government guarantee, while section 6 concludes.

\section{Estimation of the Implicit Government Guarantee}

We present the methodology used to estimate the implicit government guarantee before describing the dataset we use in this step.

\subsection{Methodology}

Government guarantee is a concept frequently used to describe the government intervention, but measuring it is a difficult issue. As the government makes no explicit commitment to rescue the firm in a default situation, the ex-ante assessment of this guarantee is challenging. We define the government guarantee as the probability that the government will step in and rescue a company in distress. To predict the probability of the government intervention we use the Logit model. The Logit model provides a way to describe a relationship between several independent variables and a binary dependant variable, expressed as a probability. As suggested by the literature and to keep the model parsimonious, we use the company size and the dummy variable indicating whether or not the firm belongs to the finance industry as explanatory variables. We have also experimented with a few other explanatory variables and different models specifications (see Table 2) and chose the more parsimonious 
model which happen to be model 2 . To predict the probability of the government intervention we fit the data to the following Logistic function:

$$
\pi_{g}=\frac{\exp \left(\beta_{0}+\beta_{s} \text { lasset }+\beta_{f} \text { Dum_Finance }\right)}{1+\exp \left(\beta_{0}+\beta_{s} \text { lasset }+\beta_{f} \text { Dum_Finance }\right)}
$$

Where, $\pi_{g}-$ the probability that the government will step in and rescue the distressed company (government guarantee);

lasset the natural logarithm of the total assets measured via their accounting value;

Dum_Finance the dummy variable indicating whether the company belongs to the financial industry or not;

After we estimate the above logistic equation, the resulting values are used in conjunction with the company size and its financial industry membership to construct a government guarantee variable for each of the companies that we use in our subsequent research.

\subsection{Government Guarantee Data}

To estimate the implicit government guarantee we use the set of 1209 companies. This data set includes both bankrupt and bailout companies over the period from 2000 to 2010. We use the list of bankrupt companies from UCLA-LoPucki Bankruptcy Research Database. ${ }^{1}$ We define the bailout companies as all firms bailed out by the government from 2000 to 2010. Any bailout in our study involves an injection of government money. The list of such companies is

\footnotetext{
${ }^{1}$ A sample of bankrupt companies' data can be found on the website: http://lopucki.law.ucla.edu/ and to obtain a full list, an email can be sent to the website author.
} 
available from ProPublica's website. ${ }^{2}$ As presented in Table 1, we have 884 bankrupt companies; $13.57 \%$ of them are from the finance industry. Our data sample also includes 325 companies bailed out by the government; $93.54 \%$ of them are the financial institutions. The correlation between the finance dummy variable and the bailout dummy variable is $75.48 \%$ and the correlation between the assets size variable and the bailout dummy is $35.96 \%$.

\section{Relationship with the CDS spread}

With the implicit government guarantee, investors adjust their perception of the company's risk of default. To understand whether the implicit government guarantee affects the investors' perception of the company's risk of default, we explore the relationship between the government guarantee variable constructed in the previous section and the CDS spreads. The CDS spread is a premium that must be paid by a protection buyer to the protection seller annually over the life of the contract, expressed in basis points. Since the CDS spread is a good proxy for the level of the company's default risk, we expect it to be negatively related to the level of the implicit government guarantee.

\subsection{The CDS Spread Regression Specification}

To relate the CDS spreads to the implicit government guarantee we use a panel regression. The panel regression is a method typically used to analyze multi-dimensional data. Since our data set includes both cross sectional and time series data, the panel regression is a suitable procedure. For our analysis we chose the constant coefficient panel regression model which is an OLS regression on a pooled data. In our regression we include the government

\footnotetext{
${ }^{2}$ For the list of government bailout companies follow the link: http://www.propublica.org/special/governmentbailouts. Here, bailouts are defined by specific programs (e.g. TARP) through which the government provides financial help to prevent companies from default.
} 
guarantee variable as well as additional firm-specific and macroeconomic control variables described in the next section:

$$
C S_{i, t}=\beta_{0}+\beta_{g} \pi_{g, i, t-1}+\beta_{f} \text { Firm }_{i, t-1}+\beta_{m} \text { Macro }_{t-1}+u_{i, t}
$$

Where, $\pi_{g, i, t-1} \quad$ the implicit government guarantee;

Firm $_{i, t-1} \quad$ firm-specific variables; and

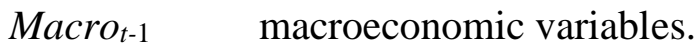

We define the $C S_{i, t}$ as a relative CDS spread of the company $i$ at time $t .{ }^{3}$ The relative CDS spread is computed by taking the midpoint between the bid and the ask quotes for the firm and dividing it by the five-year T-bond rate. The main rational for such definition of the relative CDS spread is that the CDS spread is approximately the difference between the corporate bond yield and the risk-free rate. Note that all the explanatory variables are lagged by one time period (i.e., one day). This is done to avoid simultaneity problem. We first run the regression with only the government guarantee variable. Then, we add various firm-specific control variables, such as equity volatility, firm credit ratings, leverage, and various macroeconomic variables as suggested by the empirical literature.

\footnotetext{
${ }^{3}$ We use the relative CDS spread instead of the absolute spread in order to control for the risk-free rate over which the spread is implicitly based. While the absolute CDS spread should provide a good estimate of the risk level across firms at a given point in time, from a time series perspective, the level of the risk-free rate may affect the spread, as investors tend to make a tradeoff between corporate bonds and treasuries. For the same corporate risk level, investors will require a larger spread to switch to corporate bonds when treasury rate is larger. For instance, let's suppose that for a given company on day 1 the risk-free rate is $0.2 \%$ and the CDS spread is $1 \%$, while on day 2 the risk-free rate is $5 \%$. Assuming that the underlying risk level for that company remains the same for these two days, an investor who on day 1 was indifferent between $0.2 \%$ interest rate on treasury and $1.2 \%$ yield on corporate bond, will more likely prefer $5 \%$ interest rate on treasury to $6 \%$ yield on corporate bond. This will push the yield higher and the spread (which follows the difference with the treasury rate) will increase. The relative CDS spread is a way to adjust for this time varying effect of the risk-free rate, while remaining equivalent to the absolute CDS spread in cross-section. One may think of a linear adjustment and assume that the treasury rate as a regressand is sufficient, however, we believe that a proportional adjustment is more appropriate.
} 


\subsection{CDS Data}

Our CDS data sample consists of the US companies listed on Bloomberg as of May 2010. We use daily data for the period from January 2000 through May 2010 and we focus on 5-year CDS contracts. The CDS data were available for 1,421 companies in nine industry segments. However, not every company offered information about all other independent variables. Out of 1,421 filings, only 363 offered insight into their historical CDS spreads as well as all other independent variables. In our analysis we used only complete listings, so our final sample consists of 363 firms. Out of these firms, about 10\% come from the finance industry. Note, companies that offered limited CDS data were included into the data sample, therefore, the resulting data set is unbalanced.

\subsection{Firm Specific Variables}

In our regressions we use a number of firm specific control variables that can potentially explain the variation of the CDS spreads.

\section{Equity Implied Volatility.}

Zhang, Zhou and Zhu [2009] find that volatility risk alone predicts about 50\% of the variation in the CDS spread levels. Furthermore, Cao, Yu and Zhong [2010] find that putoption implied volatility dominates historical volatility in explaining the time-series variation in CDS spreads. In our study we use the average daily implied volatility of the firm call and put options available from Bloomberg as a proxy for volatility. We expect it to be positively related to the CDS spreads because higher volatility increases probability of firm's default. 
2. Leverage

We compute the leverage ratio as:

\section{$\underline{\text { Total Liabilities }}$ \\ Total Assets}

The data was obtained from COMPUSTAT. Since accounting data is only available at the quarterly level, we use linear interpolation to obtain daily data. Just like equity return, leverage can be used as an indicator of firm's financial health. We expect positive relationship between firm's leverage and the CDS spreads.

\section{Credit Ratings}

Credit ratings reflect general credit worthiness of the company and its ability to make payments. In our regressions we use a dummy variable that takes the value of 1 if the company's credit rating is A- or higher, and 0 if it is below. The credit rating data was collected from Bloomberg. We use ratings provided by Standard \& Poors rating agency. Whenever the ratings by $\mathrm{S} \& \mathrm{P}$ are not available, we use the ratings by Moody's. We expect negative relationship between the CDS spreads and company's credit rating.

\section{Liquidity Risk}

The liquidity risk can be thought of as an ability to trade large quantities of securities quickly without causing significant changes in the market prices. We compute the liquidity risk as the CDS bid-ask spread divided by the mid-value of the bid and ask. Bidask spread is the most widely used proxy for the liquidity risk. Security is considered to be liquid if it has small bid-ask spread. The theoretical literature on whether liquidity should have a positive or negative effect on the CDS spreads is ambiguous. For example, 
Tan and Yan [2007] find that relative CDS spreads tend to increase with the bid-ask spread. Acharya and Johnson [2007] find weak negative relationship between the CDS spreads and the relative bid-ask spread. More recently, Pires, Pereira and Martins [2011] find that the CDS premiums increase with the absolute bid-ask spreads and decrease with the relative bid-ask spreads.

\subsection{Macroeconomic Variables}

In our analysis we also control for four macroeconomic variables that can potentially explain the variations in the CDS spreads. All of our macroeconomic data were obtained from Bloomberg. We discuss each of these variables individually:

i. Treasury rate

In our analysis we use a series of 5-year Treasury rates. The theoretical literature on whether the spot interest rates should have a positive or negative effect on the CDS spreads is ambiguous. Longstaff and Schwartz [1995] find that credit spreads are negatively related to interest rates because higher interest rates reduce probability of default which in turn reduces the credit spreads. Negative relationship was also found by Collin-Dufresne, Goldstein and Martin [2001] and Ericsson, Jacobs and Oviedo [2009]. However, high interest rates can also be related to tightened monetary policy. For example, Zhang, Zhou, and Zhu [2009] find that short term interest rates have significant positive effects on the CDS spreads which they connect to changes in monetary policy.

\section{ii. Short-term interest rate}

We use a 6-month LIBOR rate and its effect on the CDS spreads is ambiguous due to the same reasoning as for the Treasury rate. 
iii. Slope of the treasury yield curve

We compute the slope of the treasury yield curve as the difference between a10-year rate Treasury rate and a 2-year Treasury rate. The slope of the yield curve is an indicator of expectation of future interest rates. The expected effect of the slope on the CDS spreads is ambiguous. The slope can be considered an indicator of the overall economic health. If the term structure has a positive slope, this is considered to be an indicator of "good times". If this is the case the relationship between the slope and the CDS spreads should be negative. Significant negative relationship between the slope of the yield curve and the CDS spreads was found, for example, by Cao, Yu, and Zhong [2010]. However, the positive slope of the yield curve can also be connected to the economic environment with rising inflation and tightened monetary policy. In this case the relationship between the slope and the CDS spreads will be positive. Significant positive relationship between the slope of the yield curve and the CDS spreads was found, for example, by Zhang, Zhou, and Zhu [2009].

iv. $\quad$ S\&P 500 daily return

We use closing values of S\&P500 index to compute S\&P500 daily return. Since higher market returns are related to improved market conditions, we expect negative relationship between index returns and the CDS spreads.

Expected signs on the coefficients of the regression of the relative CDS spreads against the described explanatory variables are summarized in Table 4. 


\subsection{Summary Statistics}

Table 3 presents summary statistics of the CDS spreads and explanatory variables used in the CDS regressions. Due to missing observations, we have to deal with unbalanced panel data. The number of firms with representative number of observations varies depending on the variable. The portion of the finance companies in our CDS data sample is about $10 \%$ and about $39 \%$ of the firms have credit rating of A- or higher. The average size of the company is small, with about $\$ 16,800$ million in total assets on average. The average CDS spread is 152.16 basis points with large standard deviation. The mean leverage for all companies is about $66 \%$ and average equity volatility is about $38 \%$.

\section{Empirical Analysis}

The empirical analysis follows the steps defined above. We investigate the implicit government guarantee results first, and then analyze its relation with the CDS spreads.

\subsection{Implicit Government Guarantee}

Consistent with the common belief, we find that both the firm's size and its finance industry membership are related positively to the implicit government guarantee (see Table 2). Analyzing the size effect on the financial and non-financial industry, we find no evidence of a significant difference between the two (see Table 2, Model 1). The best model specification is Model 2, which estimates the government guarantee based on the size variable and the dummy variable of finance industry membership, and therefore, this is the specification we use in our further analysis. ${ }^{4}$

\footnotetext{
${ }^{4}$ The choice of model 2 is justified by its parsimony. Although model 1 has a slightly higher pseudo- $\mathrm{R}^{2}$, a test comparing both models shows that the difference is not significant enough to justify the inclusion of the additional
} 
We construct the implicit government guarantee variable for the sample of 363 firms. The average probability of the government bailout for all firms between year 2000 and 2010 is 0.1155 (see Table 5). However, the average government guarantee varies significantly depending on whether the firm belongs to the finance industry or not. We find that the average government guarantee for finance firms is 0.8279 , whereas for non-finance firms it is only 0.0181 . The government guarantee also varies by creditworthiness of the company. We find that companies with higher credit ratings are slightly more likely to be bailed out by the government. The same result holds for both finance and non-finance companies. Additionally, we observe that the government guarantee depends on company's size with large companies being more likely to receive the government bailout (see Figure 1). This result holds for both finance and non-finance firms.
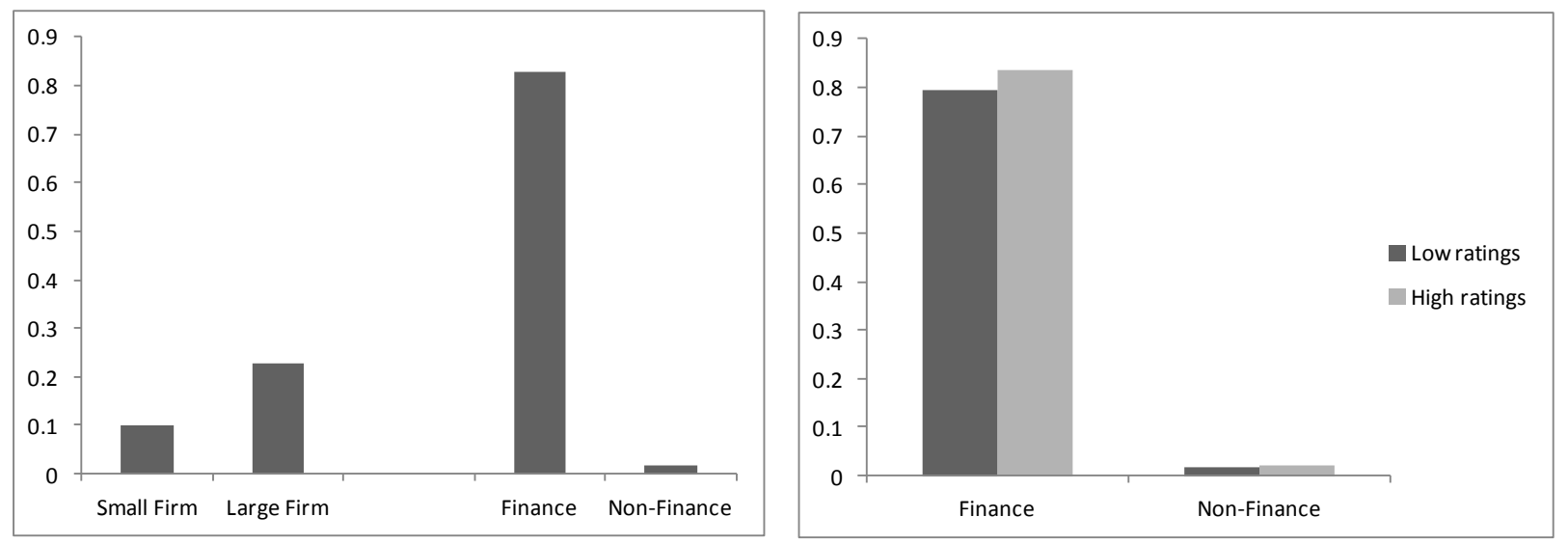

Figure 1: Average implicit government guarantee by firm size, finance membership, and firm rating. 
Figure 2 analyzes the evolution of the implicit government guarantee across time for all companies and separately for finance and non-finance firms. We observe that there was a downward shift in the probability of the government bailout after the latest financial crisis. This effect is more profound for non-financial firms. For financial firms we observe some decrease in the implicit government guarantee in 2007-2008 and an increase in 2009. Our data sample is dominated by small non-financial firms. Many similar firms failed and were not bailed out by the government during the latest financial crisis. Most of the firms that received government subsidies were financial firms. This is consistent with the high probability of the government bailout for the financial firms and low probability for the non-financial firms that we observe.

The relative stability of the bailout probability of finance companies may seem counterintuitive. In the political environment of 2007-2008 the debate about the end of "TooBig-to-Fail" led some investors to lower their expectations about the probability of government intervention. Furthermore, letting Lehman Brothers collapse sent a negative signal that weakened the government guarantee. At the same time the government passed a bailout plan to save the financial system. This somewhat mitigated the drop in probability of government intervention for financial companies, even though the overall probability decreased. This result is particularly interesting in the sense that it confirms that during the crisis the concept of "Too-Big-to-Fail" was questioned, while, at the same time, the financial companies remained more likely to be bailed-out. 

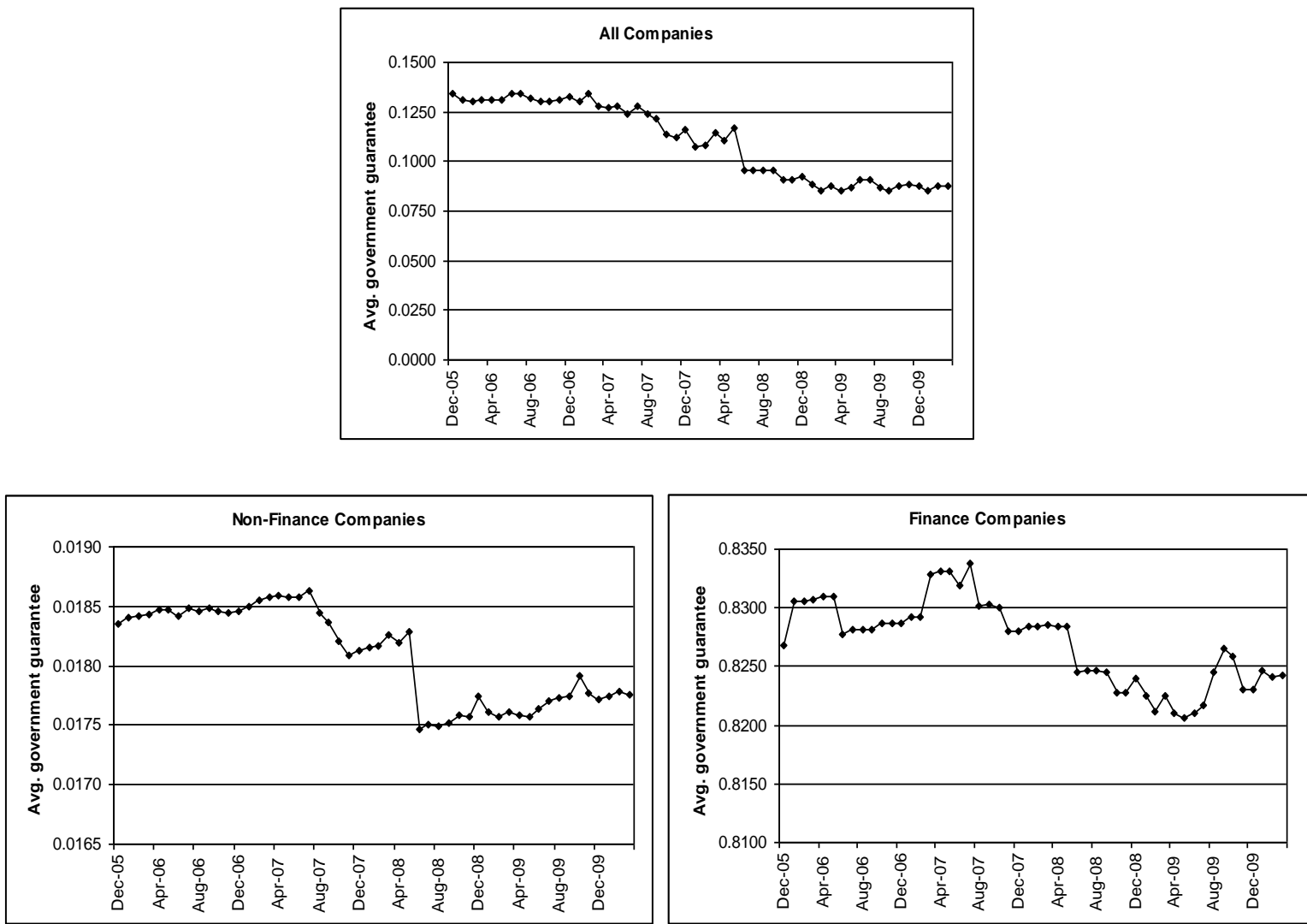

Figure 2: Average implicit government guarantee across time for all firms, finance and nonfinance firms.

\subsection{The CDS Spread Regressions}

Our main findings from the regressions that relate the CDS spreads to the implicit government guarantee and other firm specific and macroeconomic variables are reported in Table 6. Model 1 is a base line regression of the CDS spreads against the implicit government guarantee, model 2 adds the firm-specific control variables to the base model, model 3 adds macroeconomic control variables to the base model, model 4 adds all of the control variables to the base model, and model 5 analyzes the effects of the business cycle. Empirical results show that relative CDS spreads are strongly negatively related to the implicit government guarantee. This result holds across all model specifications and the effect remains strong even after including all of the control variables. This means that the higher the likelihood of the government 
to step in and rescue the troubled company, the less the company is viewed as risky and the lower the price of the default risk associated with its bonds.

The effects of all the control variables are consistent with the general intuition and expectations based on relevant literature. All firm specific variables are highly significant in any model specification. The equity volatility coefficient is positive, which is in line with Zhang, Zhou and Zhu [2009] who found that volatility is the main driving factor of the CDS spreads. The leverage coefficient is also positive which is consistent with the Merton [1974] framework that predicts higher vulnerability of a firm when its leverage ratio increases and approaches unity. As expected, the credit ratings are negatively related to the CDS spreads indicating that firms with higher credit ratings have lower CDS spreads.

Finally, we find that the liquidity coefficient is positive demonstrating that the firm's illiquidity increases the CDS spreads. Coefficients associated with the interest rates and the slope macroeconomic variables are all negative and highly significant in all model specifications. Both the short term interest rate represented by the Libor rate and the five-year T-bond rate are negative related with the CDS spreads, which is consistent with Longstaff, Mithal, and Neis [2005], Longstaff and Schwartz [1995] and other papers who found that an increase in the interest rates reduces company's default probability which, in turn, reduces the credit spreads. The coefficient of the slope variable is also negative which is consistent with the interpretation of the slope variable as an indicator of "good times". Finally, the S\&P 500 return coefficient is negative, just as expected, but insignificant.

To relate the government guarantee to the business cycle, specifically, how the government actions affect the CDS spreads during the economic crisis, we introduce a dummy variable to account for the changes after January 2007. The results in Tables 6 show a stronger 
effect of the government guarantee on the CDS spreads after this date, suggesting that just before or during the crisis investors price the government guarantee more.

To analyze the industry and the size effect on the CDS spreads we split our data sample into financial and non-financial firms and into small and large firms. To split the dataset into the large and small companies we used the cutoff value of lasset at 9.9214, which is our data set median. The average value of the lasset variable for the "small" data set is 8.7767 and the average lasset value for the "large" data set is 11.3550 . The regression results are reported in Table 7. It shows that the government guarantee variable is significant for all four regressions and the rest of the control variables (except for the S\&P500 return variable) are all highly significant and have expected signs. The effect of the government guarantee is larger for the large companies. To get the actual contribution of the government guarantee to the CDS spreads, we can multiply the regression coefficients by the average government guarantee for the data sample and then by the average five-year T-bond rate. The government guarantee for the large companies reduces the CDS spread by about 16.11 bps and for the small companies only by about 3.73 bps. Similarly, for the finance industry we obtain that the government guarantee reduces the CDS spread by about 76.29 bps and for the non-finance industry only by about 7.50 bps. This suggests that the size of the company (Too-Big-to-Fail) affects the CDS spreads mainly within the financial industry. As financial firms are usually more connected with the whole economy, this can be seen as the Too-Interconnected-to-Fail implication.

\section{Other Implications of the Implicit Government Guarantee and its Relationship with the CDS Spreads}

For a company the gain from the government intervention goes beyond the cash it receives for its rescue. The company will have a direct benefit from its own bailout and the 
indirect benefit from the rescue of the system. When appropriate, the government intervention eventually creates additional value for the system. For instance, Veronesi and Zingales [2010] estimate that the U.S. Government intervention in the financial sector, which was announced in 2008 , increased the value of the banks' financial claims by $\$ 131$ billion at a cost to taxpayers of \$25 -\$47 billion with a net benefit between \$84 and \$107 billion. Previously, O’Hara and Shaw [1990] found that the public announcement by the Comptroller of the Currency in 1984 that 11 largest banks were "Too-Big-to-Fail" increased valuation of these banks by $1.3 \%$ on average and decreased valuation of those banks suspected not to be in that group.

\subsection{Investors Perspective}

Ex-ante, the estimate of the dollar value of the government guarantee for a given firm should account for both direct and indirect benefits. While the direct gain can be inferred from the amount used to bailout the company, it is difficult to estimate the indirect gain as it includes systemic factors and the interconnection between the companies. In efficient markets the overall benefit of the government guarantee should be reflected in the CDS spreads.

Our approach can help estimate the dollar value of the implicit government guarantee for bondholders using the relationship between the CDS spread, the probability of default, and the bond yield. ${ }^{5}$ When the government guarantee becomes explicit (e.g. following a bailout plan announcement), the impact on the probability of default can be derived using the risk neutral implied volatility. For instance, Veronesi and Zingales [2010] estimate that the announcement of the 2008 bailout decreases the default probability of eight US biggest financial institutions on average by more than half, with Morgan Stanley as the biggest beneficiary.

\footnotetext{
${ }^{5}$ For the details about the link between the CDS spread, the probability of default, and the bond yield, see Hull [2012].
} 
While the bondholders extract significant gain from the government intervention through the reduction of the CDS spreads, it is less likely the case for the shareholders as the government maintains a share of the company at a cheap price during the process. An implication of this is that an equity portfolio can be hedged by bond related products to mitigate the risk in case of a bailout.

Our results show strong relationship between the state of the economy and the impact of the government guarantee on the CDS spreads. We find that after January 2007, investors strongly price the likelihood of the government to step in. As noted above, this may be due to the increase in indirect benefits as any potential bailout will be large and involve many companies in the system. This finding is another indication in favor of appropriate diversification between equity and bonds, especially using products from the finance sector which is more likely to be rescued in case of troubles.

\subsection{Regulator Perspective}

The implicit government guarantee poses a serious issue to regulators as it may lead to a moral hazard problem associated with the management of "Too-Big-to-Fail" and "TooInterconnected-to-Fail" companies. Although the expectation that the government will intervene has a positive impact on the financial system as it reduces the risk of bankruptcy and increases the enterprise value, the cost is usually supported by the tax payers.

Another implication of the relationship between the government guarantee and the CDS spread is for the regulatory capital whose estimation is based on the assessment of the default risk. Implying the default risk of a company from the CDS spreads incorporates the implicit government guarantee. This can lead to an underestimation of the actual probability of default (without government intervention). As the regulators should protect both the Wall Street and the 
Main Street, having an estimate of the risk of default without government intervention at the expense of tax payers is more appropriate. Therefore, probability of default implied from the CDS spreads should be adjusted to account for potential government intervention. Although the actual steps for such adjustment are beyond the scope of this paper, we provide some insights for this exercise.

\section{Conclusion}

After providing a formal intuitive definition of the implicit government guarantee, we use a simple and well elaborated approach to estimate it. Unlike other papers that assess the implicit government guarantee in terms of its value, we define it as the likelihood of the government to step in and rescue a troubled company. Using a unique sample of data on bailout and bankrupt companies, we estimate a logistic function to characterize the implicit government guarantee for any company in relation with its size and finance industry membership. In the second step we

relate the CDS spreads to the implicit government guarantee, and control with the traditional variables.

Empirical results show that the size of the company is secondary in the decision of the government to bail it out. The main decisive factor is whether or not the firm belongs to the finance industry. Although companies with high ratings are more likely to be rescued, their advantage over low rated companies is very small. We also find that the implicit government guarantee is priced in the CDS spreads, especially of the financial companies, and therefore, the firm's probability of default implied by the CDS spreads may be biased.

An important implication of our research is related to the regulatory capital which, when implied from the CDS spreads, should be adjusted to account for the implicit government guarantee. How to perform such adjustment and how to relate this new measure of the 
government guarantee to the actual value of the bailout with its relation to the business cycle are challenging issues which will be addressed in our future research. 


\section{References}

1. Acharya, Viral and Timothy Johnson, 2007, "Insider Trading in Credit Derivatives," Journal of Financial Economics, 84(1), 110-141.

2. Baker, D. and McArthur, T., 2009, "The Value of the 'Too Big to Fail' Big Bank Subsidy," CERP Reports and Issue Briefs, 36, Center for Economic and Policy Research.

3. Balachandran, S., Kogut, B., and Harnal, H., 2010, "The Probability of Default, Excessive Risk, and Executive Compensation: A Study of Financial Services Firms from 1995 to 2008” Working Paper, Columbia University.

4. Black, F., and Scholes, M., 1973, "The Pricing of Options and Corporate Liabilities," Journal of Political Economy, 81(3), 637-654.

5. Cao, Charles, Fan Yu, and Zhaodong Zhong, 2010, "The Information Content of OptionImplied Volatility for Credit Default Swap Valuation," Journal of Financial Markets, 13, $321-343$.

6. Collin-Dufresne, P., Goldstein, R., Martin, S., 2001, “The Determinants of Credit Spread Changes," Journal of Finance, 56, 2177-2207.

7. Ericsson, J., K. Jacobs, and R. Oviedo-Helfenberger, 2009, "The Determinants of Credit Default Swap Premia,” Journal of Financial and Quantitative Analysis, 44(1), 109-132.

8. Gapen, Michael, 2009. "Evaluating the Implicit Guarantee to Fannie Mae and Freddie Mac Using Contingent Claims” International Finance Review, 10, 329-352.

9. Haldane, A.G. 2010, “The \$100 Billion Question,” Working Paper, Bank of England. 
10. Hull, John C., 2012, "Risk Management and Financial Institutions", $3^{\text {rd }}$ Edition, John Wiley \& Son.

11. Li, Z., Qu, S., and Zhang, J., 2011, "Quantifying the Value of Implicit Government Guarantee for Large Financial Institutions," Moody's Analytics, Quantitative Research Group, January.

12. Longstaff, Francis, Sanjay Mithal, and Eric Neis, 2005, "Corporate Yield Spreads: Default Risk or Liquidity? New Evidence from the Credit-Default-Swap Market," Journal of Finance, 60, 2213-2253.

13. Longstaff, Francis A., and Eduardo Schwartz, 1995, “A Simple Approach to Valuing Risky Fixed and Floating Rate Debt," Journal of Finance, 50, 789-821.

14. Lucas, D, and McDonald R., 2009, "Valuing Government Guarantees: Fannie and Freddie Revisited," Working Paper.

15. Merton, R., 1974, "On the Pricing of Corporate Debt: the Risk Structure of Interest Rates," Journal of Finance, 29, 449-470.

16. Merton, R., 1977, “An Analytic Derivation of the Cost of Loan Guarantees and Deposit Insurance: an Application of Modern Option Pricing Theory," Journal of Banking and Finance, 29, 3-11.

17. Noss, J., and Sowerbutts, R., 2012, “The Implicit Subsidy of Banks,” Financial stability paper N15, May. 
18. O'Hara, M., and W. Shaw, 1990, "Deposit Insurance and Wealth Effects: The Value of Being 'Too Big to Fail'." Journal of Finance 45(5): 1587-1600

19. Oxera, 2011, "Assessing State Support to the UK Banking Sector," report by Oxera Consulting Ltd.

20. Pires, P., Pereira, J.P., and L.F. Martins, 2011, "The Complete Picture of Credit Default Swap Spreads - a Quantile Regression Approach," Working Paper.

21. Tang, Dragon, and Hong Yan, 2007, "Liquidity and Credit Default Swap Spreads,” Working Paper.

22. Ueda, K., and di Mauro, B., 2012, “Quantifying Structural Subsidy Values for Systemically Important Financial Institutions," IMF Working Paper N128.

23. Veronesi, Pietro and Zingales, Luigi, 2010, "Paulson's gift," Journal of Financial Economics, 97(3), 339-368

24. Zhang B. Y., H. Zhou and H. Zhu, 2009. "Explaining Credit Default Swap Spreads with the Equity Volatility and Jump Risks of Individual Firms," Review of Financial Studies, 22 (12): 5099-5131. 


\begin{tabular}{|c|c|}
\hline Variables & definition \\
\hline Gvt. guarantee & Probability of the government to step in and rescue the firm from default \\
\hline Dum_Bailout & Dummy variable taking value 1 if the firm is bailout, and 0 if not \\
\hline Dum_Finance & Dummy variable taking value 1 for finance firm, and 0 for non-finance firm \\
\hline cds spread & Basis points paid as a premium to cover five-year corporate bond \\
\hline relative cds spread & The CDS spread divided by the five-year T-bond rate \\
\hline $\operatorname{dum} 2007$ & Dummy variable taking value 1 after January $1^{\text {st }}, 2007$, and 0 before \\
\hline lasset & The natural logarithm of the total asset of the firm \\
\hline Equity volatility & The average daily implied volatility from the firm call and put option \\
\hline Leverage & The total liability divided by the total asset \\
\hline Liquidity risk & The Bid-Ask spread of the CDS spread divided by the mid-value of Bid and Ask \\
\hline Dum_Rating & Dummy variable taking value 1 if the firm is rating A- or more, and 0 if it is below \\
\hline Equity price & The closing market price of the equity \\
\hline SP500 index & The closing value of the SP500 index \\
\hline Libor rate & The six month LIBOR rate \\
\hline Five-year T-bond rate & The five-year rate on government bond \\
\hline
\end{tabular}


Table 1: Summary statistics for bailout and bankrupt firms in relation with the industry (finance or not) and their size

Panel A: Distribution of bankrupt and bailed out firms by industry.

\begin{tabular}{|c|c|c|c|}
\hline \multirow[b]{2}{*}{ Dum_Bailout } & \multicolumn{3}{|c|}{ Dum_Finance } \\
\hline & $\begin{array}{c}\text { Non- } \\
\text { Finance }\end{array}$ & Finance & Total \\
\hline \multirow[t]{3}{*}{ No } & 764 & 120 & 884 \\
\hline & $86.43 \%$ & $13.57 \%$ & $100.00 \%$ \\
\hline & $97.32 \%$ & $28.30 \%$ & \\
\hline \multirow[t]{3}{*}{ Yes } & 21 & 304 & 325 \\
\hline & $6.46 \%$ & $93.54 \%$ & $100.00 \%$ \\
\hline & $2.68 \%$ & $71.70 \%$ & \\
\hline Total & 785 & 424 & 1209 \\
\hline
\end{tabular}

Panel B: Summary statistics for variables used in the estimation of the government guarantee.

\begin{tabular}{lrrrrr}
\hline & Obs & Mean & Std. Dev. & Min & Max \\
\hline Dum_Bailout & 1209 & 0.2688 & 0.4435 & 0 & 1 \\
Dum_Finance & 1209 & 0.3507 & 0.4774 & 0 & 1 \\
lasset & 1162 & 6.9743 & 1.4759 & 5.1120 & 12.7005 \\
\hline
\end{tabular}

Panel C: Correlation coefficients.

\begin{tabular}{llll}
\hline & Bailout & $\begin{array}{l}\text { Finance } \\
\text { Industry }\end{array}$ & lasset \\
\hline Dum_Bailout & 1 & & \\
Dum_Finance & 0.7548 & 1 & \\
lasset & 0.3596 & 0.4017 & 1 \\
\hline
\end{tabular}


Table 2: Logit regression of the variable "Dum_Bailout" for the estimation of the probability of the government intervention (Government guarantee) using the sample of bailout and bankrupt firms over the last decade $(2000-2010)$

\begin{tabular}{|c|c|c|c|c|c|}
\hline Variables & Model 1 & Model 2 & Model 3 & Model 4 & Model 5 \\
\hline Dum_Finance & $\begin{array}{c}7.2194 * * * \\
{[3.85]}\end{array}$ & $\begin{array}{c}5.1975 * * * \\
{[13.81]}\end{array}$ & $\begin{array}{c}4.2416 * * * \\
{[6.74]}\end{array}$ & $\begin{array}{c}4.5236 * * * \\
{[18.38]}\end{array}$ & \\
\hline lasset & $\begin{array}{c}0.4362 * \\
{[1.78]}\end{array}$ & $\begin{array}{c}0.1643^{* *} \\
{[2.49]}\end{array}$ & & & $\begin{array}{c}0.5431 * * * \\
{[10.84]}\end{array}$ \\
\hline lasset $\times$ Dum_Finance & $\begin{array}{c}-0.2883 \\
{[1.14]}\end{array}$ & & $\begin{array}{c}0.1463 * * \\
{[2.20]}\end{array}$ & & \\
\hline Constant & $\begin{array}{c}-7.5506 * * * \\
{[4.17]}\end{array}$ & $\begin{array}{c}-5.6524 * * * \\
{[9.91]}\end{array}$ & $\begin{array}{c}-4.5591 * * * \\
{[12.83]}\end{array}$ & $\begin{array}{c}-3.5940 * * * \\
{[16.25]}\end{array}$ & $\begin{array}{c}- \\
5.0664 * * * \\
{[13.54]}\end{array}$ \\
\hline Pseudo $\mathrm{R}^{2}$ & 0.5599 & 0.5590 & 0.5578 & 0.5035 & 0.1088 \\
\hline Observations & 1162 & 1162 & 1162 & 1209 & 1162 \\
\hline
\end{tabular}

Absolute value of $t$-statistics in brackets

$*$ significant at $10 \%$; ** significant at $5 \%$; *** significant at $1 \%$ 
Table 3: Summary statistics

\begin{tabular}{lccccr}
\hline Variable & \multicolumn{1}{c}{ Obs } & \multicolumn{1}{l}{ Mean } & Std. Dev. & Min & Max \\
\hline absolute cds spread & 431,084 & 152.16 & 352.96 & 4.83 & 89102.50 \\
relative cds spread & 385,615 & 60.22 & 173.96 & 1.01 & 19153.18 \\
Gvt. guarantee & 918,465 & 0.10 & 0.24 & 0.01 & 0.88 \\
dum2007 & 933,660 & 0.36 & 0.48 & 0.00 & 1.00 \\
Dum_Finance & 933,660 & 0.10 & 0.30 & 0.00 & 1.00 \\
lasset & 918,465 & 9.73 & 1.64 & 4.38 & 16.74 \\
Equity volatility & 849,241 & 38.15 & 20.89 & 6.38 & 478.04 \\
Leverage & 918,465 & 0.66 & 0.18 & 0.04 & 1.84 \\
Liquidity risk & 431,084 & 0.12 & 0.08 & -1.49 & 1.80 \\
Dum_Rating & 706,932 & 0.39 & 0.49 & 0.00 & 1.00 \\
SP500 index & 872,784 & 1184.24 & 195.86 & 676.03 & 1565.18 \\
Libor rate & 783,601 & 2.63 & 1.81 & 0.10 & 6.88 \\
Five-year T-bond rate & 873,822 & 3.83 & 1.15 & 1.26 & 6.81 \\
\hline
\end{tabular}


Table 4: Expected signs on the coefficients of the regression the relative CDS spread against explanatory variables.

\begin{tabular}{ll}
\hline Variable & Expected Sign \\
\hline Gvt. guarantee & Negative \\
Equity volatility & Positive \\
Leverage & Positive \\
Dum_Rating & Negative \\
Liquidity risk & Ambiguous \\
Five-year T-bond rate & Ambiguous \\
Libor rate & Ambiguous \\
Slope & Ambiguous \\
SP500 index & Negative \\
\hline
\end{tabular}

Table 5: Average implicit government guarantee by industry and credit ratings.

\begin{tabular}{llll}
\hline & All Firms & $\begin{array}{l}\text { Non-Finance } \\
\text { Firms }\end{array}$ & Finance Firms \\
\hline Low ratings & 0.0460 & 0.0167 & 0.7943 \\
High ratings & 0.1990 & 0.0210 & 0.8354 \\
All & 0.1155 & 0.0181 & 0.8279 \\
\hline
\end{tabular}


Table 6: Robust OLS regression of the relative CDS spread on government guarantee, firm characteristics and some macro-variables. Independent variables are delayed by one lag (day)

\begin{tabular}{|c|c|c|c|c|c|}
\hline & Model 1 & Model 2 & Model 3 & Model 4 & Model 5 \\
\hline Gvt. guarantee & $\begin{array}{c}-90.5153 * * * \\
(119.33)\end{array}$ & $\begin{array}{c}-33.0911 * * * \\
(44.04)\end{array}$ & $\begin{array}{c}-27.6380^{* * * *} \\
(69.22)\end{array}$ & $\begin{array}{c}-23.8139 * * * \\
(34.04)\end{array}$ & $\begin{array}{c}-21.5670 * * * \\
(32.52)\end{array}$ \\
\hline Equity volatility & & $\begin{array}{c}3.7128^{* * * *} \\
(80.04)\end{array}$ & & $\begin{array}{c}3.5261 * * * \\
(70.33)\end{array}$ & $\begin{array}{c}3.5279 * * * \\
(70.27)\end{array}$ \\
\hline Dum_rating & & $\begin{array}{c}-31.5696 * * * \\
(71.02)\end{array}$ & & $\begin{array}{c}-34.0109 * * * \\
(74.04)\end{array}$ & $\begin{array}{c}-33.9273 * * * \\
(73.90)\end{array}$ \\
\hline Leverage & & $\begin{array}{c}128.2403^{* * * *} \\
(59.76)\end{array}$ & & $\begin{array}{c}130.5102 * * * \\
(59.48)\end{array}$ & $\begin{array}{c}130.3980^{* * *} \\
(59.49)\end{array}$ \\
\hline Liquidity risk & & $\begin{array}{c}82.1113^{* * *} \\
(18.29)\end{array}$ & & $\begin{array}{c}100.7275^{* * * *} \\
(26.13)\end{array}$ & $\begin{array}{c}99.1654 * * * \\
(26.06)\end{array}$ \\
\hline SP500 return & & & $\begin{array}{c}-17.5405 \\
(0.54)\end{array}$ & $\begin{array}{c}-42.958 \\
(1.56)\end{array}$ & $\begin{array}{c}-42.4033 \\
(1.54)\end{array}$ \\
\hline Libor rate & & & $\begin{array}{c}-10.6544^{* * * *} \\
(30.29)\end{array}$ & $\begin{array}{c}-15.0732 * * * \\
(45.00)\end{array}$ & $\begin{array}{c}-14.6825 * * * \\
(43.16)\end{array}$ \\
\hline Slope & & & $\begin{array}{c}-59.5017 * * * \\
(52.72)\end{array}$ & $\begin{array}{c}-36.4757 * * * \\
(45.58)\end{array}$ & $\begin{array}{c}-36.2104 * * * \\
(45.28)\end{array}$ \\
\hline Five-year T-bond rate & & & $\begin{array}{c}-83.8283^{* * * *} \\
(91.69)\end{array}$ & $\begin{array}{c}-14.3732 * * * \\
(22.32)\end{array}$ & $\begin{array}{c}-14.7554 * * * \\
(22.94)\end{array}$ \\
\hline Gvt. guarantee $\times$ dum 2007 & & & & & $\begin{array}{c}-7.5533 * * * \\
(7.49)\end{array}$ \\
\hline Constant & $\begin{array}{c}73.5576^{* * *} \\
(176.86)\end{array}$ & $\begin{array}{c}-163.3195^{* * *} \\
(54.48)\end{array}$ & $\begin{array}{c}452.9352^{* * * *} \\
(84.27)\end{array}$ & $\begin{array}{c}-25.6303^{* * * *} \\
(6.20)\end{array}$ & $\begin{array}{c}-25.4407 * * * \\
(6.16)\end{array}$ \\
\hline Observations & 302625 & 234641 & 292166 & 228163 & 228163 \\
\hline R-squared & 0.0154 & 0.4293 & 0.1226 & 0.4406 & 0.4406 \\
\hline
\end{tabular}

Robust $t$ statistics in parentheses

* significant at $10 \%$;* significant at 5\%; *** significant at $1 \%$ 
Table 7: Robust OLS regression of the relative CDS spread on government guarantee, firm characteristics and some macro-variables. Independent variables are lagged by one day.

\begin{tabular}{|c|c|c|c|c|}
\hline & Size & & Industry & \\
\hline & Small Comp & Large Comp. & Finance Comp. & Non-Fin Comp. \\
\hline Gvt. guarantee & $-9.7705 * * *$ & $-18.9982 * * *$ & $-23.8361 * * *$ & $-108.5005^{* * *}$ \\
\hline & $(4.34)$ & (20.33) & $(7.75)$ & (19.36) \\
\hline Equity volatility & $4.3437 * * *$ & $3.0799 * * *$ & $2.8611 * * *$ & $3.7446 * * *$ \\
\hline & $(68.20)$ & $(42.57)$ & $(28.28)$ & $(62.96)$ \\
\hline Dum_rating & -0.7728 & $-47.3761 * * *$ & $-72.9921 * * *$ & $-28.8299 * * *$ \\
\hline & $(1.27)$ & $(45.70)$ & $(24.77)$ & $(64.48)$ \\
\hline Leverage & $145.7911^{* * *}$ & $123.7569^{* * *}$ & $142.1605^{* * *}$ & $136.0902 * * *$ \\
\hline & $(50.81)$ & $(35.74)$ & (17.66) & $(57.20)$ \\
\hline Liquidity risk & $68.5058 * * *$ & $90.8705^{* * *}$ & $137.4265^{* * *}$ & $102.0955^{* * *}$ \\
\hline & (11.70) & (17.53) & (12.44) & $(25.80)$ \\
\hline SP500 return & -29.7904 & -43.3147 & -11.0487 & -41.5322 \\
\hline & $(0.93)$ & $(0.98)$ & $(0.13)$ & $(1.44)$ \\
\hline Libor rate & $-15.3510 * * *$ & $-15.5319 * * *$ & $-17.2998 * * *$ & $-14.2797 * * *$ \\
\hline & $(36.51)$ & (30.76) & $(15.51)$ & $(39.02)$ \\
\hline Slope & $-35.8695 * * *$ & $-35.6087 * * *$ & $-39.2926 * * *$ & $-35.1857 * * *$ \\
\hline & (35.34) & $(29.43)$ & $(16.67)$ & $(41.29)$ \\
\hline Five-year T-bond rate & $-10.5933^{* * *}$ & $-12.6609 * * *$ & $-5.7037 * * *$ & $-11.4999 * * *$ \\
\hline & (11.54) & (14.34) & $(3.31)$ & $(16.25)$ \\
\hline Constant & $-86.5279 * * *$ & -2.5271 & -8.799 & $-46.2918 * * *$ \\
\hline & $(13.31)$ & $(0.53)$ & $(1.03)$ & $(9.90)$ \\
\hline Observations & 108388 & 119775 & 25170 & 202993 \\
\hline $\mathrm{R}$-squared & 0.5542 & 0.3624 & 0.5416 & 0.4339 \\
\hline
\end{tabular}

Robust $t$ statistics in parentheses

* significant at 10\%; ** significant at 5\%; *** significant at $1 \%$ 